\title{
How Public Opinion Steers National Immigration Policies
}

Tobias Böhmelt

University of Essex

Department of Government

Wivenhoe Park

Colchester CO43SQ

United Kingdom

tbohmelt@essex.ac.uk

+4401206872288

\begin{abstract}
Previous research suggests that client politics shape national migration laws in that they converge towards more liberal regulations. An examination of recently released cross-country data suggests, however, that there is little support for either convergence or generally more open policies. Trying to shed light on this empirical puzzle, I argue that democratic policymakers have incentives to listen to, and pursue policies that are favored by, the "unorganized" electorate as well, since this maximizes their chances of staying in power. However, due to the influence of client interests that work against the public's view on migration, a positive effect should only materialize under more salient circumstances, i.e., when the inflow of foreign-born individuals is high. I analyze these expectations quantitatively using data that combine information on national migration policies with all European Social Survey rounds in 2002-2016. I find robust and significant support for public opinion influencing domestic immigration laws, but this effect only emerges with rather large migrant and refugee populations in the country.
\end{abstract}

Keywords: Issue Salience; Migration; Public Opinion; Public Policies; Quantitative Analysis

I thank the journal's editor, Alan Gamlen, and the anonymous reviewers for valuable comments and suggestions. 


\section{Introduction}

The movement of people across borders has risen significantly over the last few decades. According to the United Nations (2015), the total population of international migrants, i.e., people residing in a country other than their country of birth, has more than doubled since the year 2000 to about 244 million by 2015 . The scale of international migration makes it a global phenomenon, a "fundamental driver of social, economic, and political change" (Cornelius and Rosenblum 2005: 99) affecting each state worldwide. Leaving a country to live in another state abroad is determined by multiple forces (for overviews, see, e.g., Cornelius and Rosenblum 2005: 100ff; Breunig, Cao, and Luedtke 2012; Alarian and Wallace Goodman 2017) that are commonly categorized as push (e.g., poor economic conditions in the country of origin) and pull factors (e.g., freer forms of government or better economic opportunities in potential host states). Permanently moving to another country offers valuable gains for both migrants and their host societies, including economic growth (see, e.g., Cornelius and Rosenblum 2005: 103f; Dustmann and Frattini 2014; Hainmueller, Hangartner and Pietrantuono 2017); but states can also experience a number of challenges related to the supply of goods and services when trying to manage large population inflows. In light of this, laws, controls, and policies are necessary instruments for governments to regulate migration.

How are states' migration policies formed and influenced? There is a substantive body of works studying the determinants of migration laws and regulations (for overviews, see, e.g., Meyers 2000; Money 2010; Abou-Chadi 2016; Koopmans and Michalowski 2017; Helbling and Kalkum 2018; see also Joppke 2003; Cornelius and Rosenblum 2005; Hansen and Köhler 2005; Howard 2006; Sassen 2008). To a large degree, a consensus seems to have emerged in this literature, which highlights two major trends. First, migration policies, particularly across democracies, converge (e.g., Freeman 1995; Givens and Luedtke 2005; Sassen 2008). 
National governments largely retain control over their migration laws and regulations, but international and globalization influences such as the European Union (and here, most prominently, the Schengen Agreement) increasingly shape these policies and align them (see also Lahav 2004: 1153; Money 2010). Second, over the course of this convergence process, client politics are the main driver and induce more liberal rules. While (unorganized) public opinion may not necessarily prefer more open migration regulations and, in fact, generally opposes existing immigration levels (e.g., Citrin et al. 1997; Cornelius and Rosenblum 2005; Kessler and Freeman 2005; Sides and Citrin 2007; Howard 2009, 2010; Breunig et al. 2012; Abou-Chadi 2016), (democratic) governments do not translate these preferences into policies, but instead follow more organized, client interests that favor open, less restrictive policies on migration (Freeman 1995; Joppke 1999; Beck and Camarota 2002; Sassen 2008; see also Lahav 2004; Facchini and Mayda 2008). In the words of Abou-Chadi (2016: 2092; see also Givens and Luedtke 2005), "a law-making process behind closed doors with as little public attention as possible should generally favor liberalizing change." These two patterns have crucial implications for our understanding of countries' migration laws, how they are formed, and what consequences they have.

However, systematic, cross-country analyses have been rather the exception than the rule due to the lack of high-quality data covering a large set of countries over a longer period of time (see also Freeman 1995: 887; Meyers 2000; Lahav 2004: 1178; Money 2010; AbouChadi 2016: 2087). ${ }^{1}$ Recently released information on national policies from the Immigration Policies in Comparison (IMPIC) project (Helbling et al. 2017; see also Helbling and Kalkum 2018) addresses this shortcoming - but, perhaps surprisingly, these data do not seem to support the literature's two major trends outlined above. Figure 1 depicts the restrictiveness levels of states' internal immigration controls and regulations as taken from the IMPIC data

\footnotetext{
${ }^{1}$ And even existing studies trying to overcome such limitations cover a limited number of states, e.g., Givens and Luedtke (2005) focus on three countries, while Abou-Chadi's (2016) analysis is based on 11 democracies.
} 
for all countries in my sample between 2002 and 2016. Contrary to what existing work may expect, state policies in Figure 1 are characterized by a significant amount of variation (nonconvergence) and several countries have rather restrictive policies (non-openness). ${ }^{2}$ Ultimately, there is apparently little evidence for a "liberal bias" (Money 2010) in immigration policies.

Figure 1. Internal Immigration Polices, 2002-2016

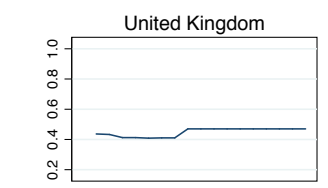

France

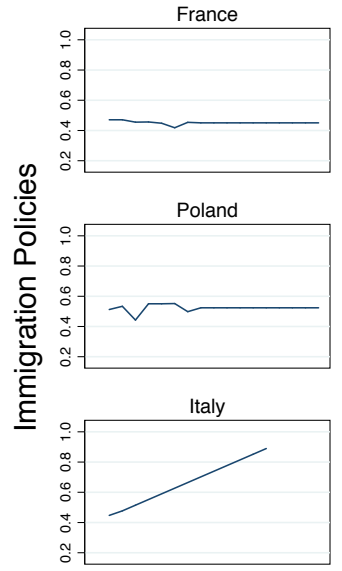

Norway

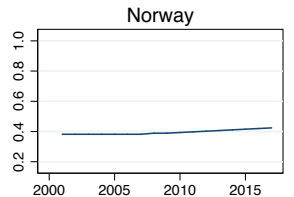

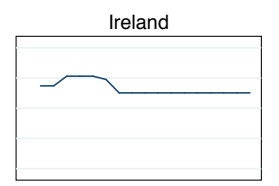

Switzerland

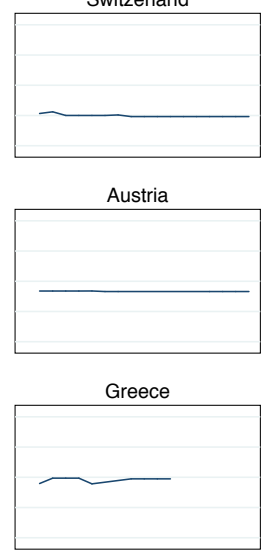

Denmark

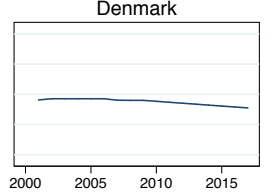

Netherlands

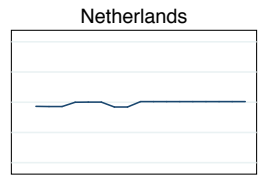

Spain

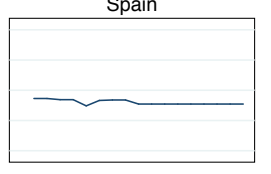

Hungary

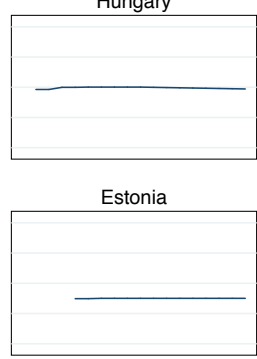

Iceland

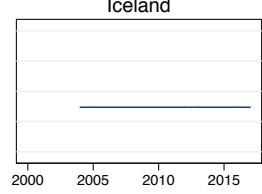

Belgium

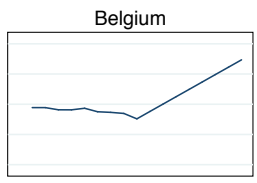

Portugal

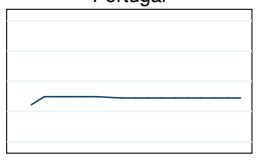

Czech Republic

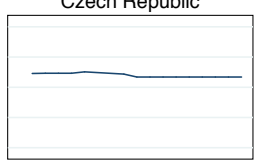

Finland

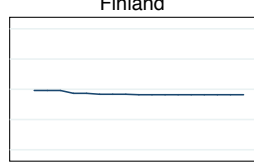

Turkey

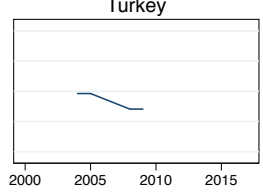

Luxembourg

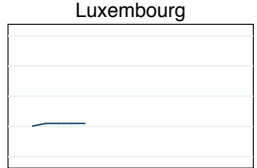

Germany

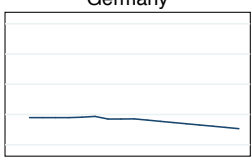

Slovakia

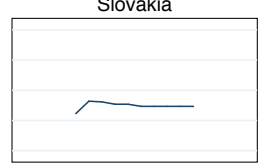

Sweden

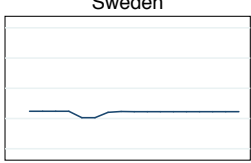

Israel

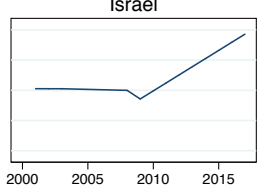

Note: Graph is based on internal immigration policy controls and regulations as defined by the Immigration Policies in Comparison (IMPIC) project (Helbling et al. 2017). The data set is described in the research-design section below. Data in 2011-2016 are linearly interpolated.

The following article seeks to shed light on this puzzle by providing new theoretical and empirical answers to why immigration laws may not necessarily converge and are less open. Two main scholarly contributions are made to this end. First, I develop an argument that (re-) emphasizes the importance of public opinion (see also Facchini and Mayda 2008) - the "unorganized interest." Focusing on a sample of democracies, I contend that democratic

\footnotetext{
2 This also mirrors Lahav's (2004) study of EU immigration policy outcomes and Abou-Chadi's (2016: 2089) findings for stay and entry regulations (see also Money 2010).
} 
governments have incentives to pursue policies that are favored by the larger public in order to maximize their chances of staying in power (see also Bueno de Mesquita et al. 2005). Domestic immigration policies are unlikely to be an exception here and, in fact, can be influenced by the public's attitude. However, due to the impact of the more organized client interests that work against the unorganized, mean voter's view on migration, a positive effect is more likely to materialize only under more salient circumstances (see also Howard 2009, 2010; Abou-Chadi 2016), i.e., when the inflow of migrants and refugees is large. Empirically, I combine public opinion data on migration attitudes of all rounds of the European Social Survey (ESS) with the recently released IMPIC data (Helbling et al. 2017) on domestic migration policies in 2002-2016. My results present evidence for the impact of client interests, but also for the influence of public opinion that exerts a significant and positive effect on the degree of restrictiveness of internal migration policy controls and regulations. The less open the public is about immigration, the more restrictive are national migration laws. However, a careful examination shows that this effect only emerges with rather large foreign-born populations in the country. In states with few migrants and refugees, public opinion does not have a significant effect on policy outputs, which suggests that the link of citizens' attitudes and national policies only becomes relevant in situations in which migration is, in fact, a salient issue.

These findings emphasize that both factors - client interests and the less organized public - are at work and can shape migration policies, but the former largely cancels out the latter until a salient point is reached at which the influence stemming from public opinion takes over - the public can no longer be "ignored" and is then more influential. This result not only explains previous findings in the literature pointing to the importance of client politics, but also the trends toward less convergence and more restrictiveness Figure 1 above depicts (see also Lahav 2004; Abou-Chadi 2016). Ultimately, my research offers crucial implications and 
contributions to policy and scholastic circles. Most importantly, I demonstrate that governments can and do respond to a broader spectrum of the electorate, not necessarily the more organized, client interests, in the context of migration policies. I discuss these implications in the conclusion.

\section{Theory: Client Politics, Public Opinion, and Issue Salience}

In general, I focus on public opinion's role for immigration policymaking when contending that policymakers have incentives to legislate laws and regulations that reflect public demand. But what are the underlying mechanisms behind this? And is this effect conditional on some moderating influence? First, it is frequently assumed that democratic leaders have a strong incentive of retaining power. When subscribing to this, second, democratic governments may want to introduce policies that favor the domestic audience. In turn, third, if the public mood is more skeptical of migration, the executive could want to introduce more restrictive migration controls and regulations, since this will improve the chances of staying in power, i.e., doing well in the next election. However, imposing restrictions on immigration also induces costs, primarily as less open policies go against what the more organized, client interest wants. Hence, legislating more restrictive laws and regulations may only be more likely if the general, less organized public can no longer be ignored - and this may rather be given in the more salient cases when sufficiently large foreign-born populations in a country exist. In the following, I develop these arguments in detail.

Democratic institutions and the procedures of leader selection in these regimes incentivize governments to respond to constituents' needs (e.g., Bueno de Mesquita et al. 2005). The primary mechanism behind this is that democratic leaders can be removed more easily from office than their non-democratic counterparts due to, e.g., regular elections, and this constrains democratic governments' policy choices (Breunig et al. 2012: 830). Democratic 
politicians thus have more incentives than other leaders to implement policies that favor their voters (Dahl 1971; see also Mirolovic 2010; Breunig et al. 2012: 830f). However, democracies have larger winning coalitions (i.e., those who control enough power to keep a leader in office), and the relative cost of providing private goods to these individuals as a means of maintaining power is therefore higher, too. As a result, democratic leaders tend to provide public goods to retain power - and immigration control and regulation, which is usually seen as a public good (Freeman 1995: 885), is unlikely to be an exception.

But how do democratic politicians supply public goods in line with voters' preferences? Put differently, how can public opinion actually influence policymaking? As indicated, democracies provide the opportunity for citizens to influence politics via multiple channels including casting their vote in elections. Since politicians are concerned about votes and can choose their policies accordingly in order to maximize chances to do well in the next election, they will adopt policy platforms that are closer to the ideal policies of the public (Downs 1957; see also Ezrow 2010). This, in turn, should lead to a greater provision of public goods desired by the general audience, i.e., more restrictive policies if the public demands this. Evidence for the responsiveness of democratic governments to voters' demands does exist (e.g., Ezrow 2010) and, even in the context of EU initiatives on immigration, Lahav (2004: 1152) suggests that policies can "broadly reflect public opinion."”

However, the influence of client interests remains an issue. In light of previous work finding evidence for its impact (e.g., Freeman 1995; Joppke 1999; Beck and Camarota 2002; Sassen 2008; see also Facchini and Mayda 2008), it seems implausible that migration laws and regulations are exclusively and continuously based on public demand (see also Baumgartner and Jones 1993; Jones 1994; Jones and Baumgartner 2005). In fact, "immigration policy making has long been made in the absence of public debate" (Lahav

\footnotetext{
${ }^{3}$ However, Lahav's (2004) analysis is of rather descriptive nature without a direct test of or systematic evidence for a link between public attitudes and policymaking.
} 
2004: 1153) and "voters' vote choice is only affected by the issues that they perceive as salient" (Abou-Chadi 2016: 2094). I therefore argue that public opinion and client interests exert an influence, but the latter largely cancels out the former due to opposing effects, all else equal. Instead, public attitudes toward migration must somehow be enhanced, enforced, or "activated" (see also Howard 2009, 2010; Abou-Chadi 2016: 2088), which induces that only in times of issue salience is it more likely that the public affects democratic governments and their policy outputs strongly and exerts an impact that can be clearly distinguished from client interests (Wlezien 1995; Givens and Luedtke 2005; Bélanger and Meguid 2008).

That is, policy change in most issue areas is usually incremental and attention not focused at the macro level (Mazey and Richardson 2006). In the context of a complex interplay of the more organized client interests and the less organized public, however, issues might break through to the macro-political realm of elected politicians if voters - and, in turn, policymakers - perceive something as extremely salient (Givens and Luedtke 2005; Bélanger and Meguid 2008). This mirrors Cornelius and Rosenblum (2005: 105) who emphasize that immigration as a policy issue has the potential to mobilize the electorate under certain conditions. That is, so that major policymaking can occur in favor of the general attitude, some factor pushing the influence of public opinion over client interests is necessary. I argue that issue salience can be such a moderating influence - a factor that "activates" public opinion (Howard 2009, 2010; see also Givens and Luedtke 2005) and policymakers can no longer (afford to) ignore what the larger public wants (see also Abou-Chadi 2016: 2092; Bélanger and Meguid 2008).

Leaders tend to process issues sequentially (Walgrave and Dejaeghere 2016) and "pressure" has to build up for policy change to happen. That is, to break through politicians' attention thresholds requires a positive feedback process. Public opinion and issue salience 
positively feed-back off each other until regulations are implemented that reflect public demand to address the issue at hand. Salience generally pertains to the importance of an issue, being a function of the scale of that matter, how likely it is that the public is affected by it (and will care about it), and public debate extended (see also Abou-Chadi 2016: 2092; see also Givens and Luedtke 2005). The actual size of foreign-born populations seems to fit these criteria: "hostility to immigration is correlated with the visibility of new migration inflows" (Cornelius and Rosenblum 2005: 105). I contend accordingly that issue salience increases with the size of the migrant and refugee population in the country (see also Ugur 1995; Money 2010). Conversely, issue salience is likely to be low if there is only a small foreignborn population. ${ }^{4}$

Broad public support for specific migration controls and regulations in combination with high issue salience are not necessary for an agenda breakthrough, but they add weight to other forces at work pushing against policy inertia or client interests (Jones and Baumgartner 2012). Thus, more salient circumstances should facilitate that public attitudes, independent and different from client politics, exert an influence on policymaking. This explains, for example, that the UK raised the level of restrictiveness of its migration laws after a significant inflow of foreign-born individuals in the 1990s (Givens and Luedtke 2005: 5). On the other hand, low issue salience combined with little public demand for migration policy restrictions makes it more likely that client politics affects decision-making and can effectively push for more liberal policies (Givens and Luedtke 2005: 7; Hansen and Köhler 2005; Abou-Chadi 2016: 2092).

Ultimately, I expect that only when migration is a salient issue, i.e., when the foreign-born population is large, policymakers have stronger incentives to reply to the broader public's

\footnotetext{
${ }^{4}$ Similarly, Lahav (2004: 1162f) emphasizes that "knowing the number of immigrants in a country tells us a great deal about people's attitudes [...], because perceptions clearly have some reality base." According to Lahav (2004: 1167, 1171) "substantial immigrant populations" equal high issue salience. Givens and Luedtke (2005: 9f) state that policy responds to "the actual societal presence of immigrants," and Koopmans and Michalowski (2017: 61) contend that "larger immigrant populations could be perceived as more threatening."
} 
demand, and less favorable attitudes toward migration will then be associated with more restrictive migration laws and regulations.

\section{Research Design}

To test my theoretical expectations, I have compiled a data set comprising information on immigration policies, public opinion on migration, transnational population movements, and a series of control variables for a sample of established, mostly European democracies between 2002 and 2016. The sample's country-time coverage is driven by data availability of the core variables of interest, most crucially public opinion as the European Social Survey (ESS) is only available as of $2002 .{ }^{5}$ The country-year is the unit of analysis in this time-series cross-sectional data set. All explanatory items are temporally lagged by one year to minimize problems stemming from endogeneity, while variables' values in years not included in the ESS between 2002 and 2016 are linearly interpolated. With these specifications, there are 25 countries in my sample (see also Figure 1 above).

\section{Dependent Variable}

The dependent variable is based on the IMPIC project, which codes national immigration policies, i.e., regulations, controls, and laws that "regulate legal access to a state's territory" (Koopmans and Michalowski 2017: 42), across four dimensions (labor migration, asylum, family reunification, and co-ethics) in OECD countries between 1980 and $2010 .{ }^{6}$ Helbling et al. (2017) comprehensively review and assess available data sets on immigration and citizenship policies and show that the IMPIC data is the most suitable for cross-country comparisons over time due to their focus on the absolute levels of restrictions. The IMPIC data make a broad distinction between regulations and control mechanisms, internally and

\footnotetext{
${ }^{5}$ Note that I also cannot cover all states included in the ESS, as the Immigration Policies in Comparison (IMPIC) project is more limited.

${ }^{6}$ Available online at: http://www.impic-project.eu. As indicated, values in 2011-2016 are linearly interpolated.
} 
externally, while regulations refer to eligibility, conditions, status, and rights. In each area, the IMPIC project measures on a quasi-continuous scale between 0 and 1 how restrictive a policy is.

For this study, I constructed an aggregated variable for internal controls and regulations, i.e., this item averages values across all internal items in the IMPIC data set to capture the mean level of restrictiveness of internal immigration policies in a country. Internal regulations pertain to, for example, the security of foreign-born individuals' status or their rights in a country (e.g., free movement or benefits granted), while internal controls are about identification documents or authorities' oversight. This variable, Immigration Policies, has a mean value of 0.529 in my sample, suggesting that immigration restrictions are historically above the theoretical average and I use it in the main models below, but also summarize a disaggregated analysis that focuses on controls and regulations, respectively, in the appendix.

Considering the scale of this dependent variable, I employ OLS regression models. Next to the substantive predictors, fixed effects for countries and years are included in all models to capture any time-invariant, unit-level forms of cross-section heterogeneity or system-wide shocks affecting all countries equally. Most political institutions that previous work has identified as important drivers of migration policy outputs (e.g., Abou-Chadi 2016) do not vary over time in my sample and Lahav (2004: 1170) also highlights country-specific contexts such as the status as a former colonial power (Koopmans and Michalowski 2017) or national identity (Money 2010). Moreover, the European refugee and migration crisis that broke out in 2015 could be one of those temporal shocks and the year fixed effects address this. I also incorporate a temporally lagged dependent variable to control for a state's restrictiveness of immigration policies in the previous year. Given the time-series crosssection structure of the data, serially correlated errors within countries might be possible and 
the temporally lagged dependent variable controls for this (Beck 2001). There is also a theoretical rationale: a lagged dependent variable captures path-dependence processes.

\section{Main Explanatory Variables}

For the independent variables, first, I employ the integrated data files of all eight rounds of the ESS between 2002 and 2016. The ESS is one of the most methodologically rigorous cross-national survey projects. While being similar to other European surveys such as the Eurobarometer, the ESS's key advantage is that survey practices are harmonized to reduce the likelihood of different results between countries being driven by alterations in how the survey is conducted in each state. To this end, the ESS has developed strict guidelines for consistent methods of fieldwork, including contacting, coding, and the implementation of random sampling, which are all enforced by a central committee. These practices require, among others, a random sampling design of residents 15 years and older (no quota sampling), one hour face-to-face interviews, a target response rate of 70 percent, and a minimum of 2,000 respondents per country. These characteristics make the ESS particularly useful for my purposes. For a discussion of the ESS data, see de Vries (2017).

I employ the ESS survey question "Is [country] made a worse or a better place to live by people coming to live here from other countries?" Respondents could assess this on a 0-10 scale with higher values pertaining more strongly to "a better place to live." I first deleted all individuals who have not responded to this question or expressed no opinion ("do not know") before inverting this item so that higher values stand for less favorable attitudes toward migrants and refugees. Afterwards, I aggregated this individual-level variable to the macro, country level by averaging across respondents. The final variable measures the public, average-voter mood toward migration in each country-year between 2002 and 2016, and it 
theoretically ranges between 0 and 10 with higher values indicating that public opinion sees migration less favorably.

Issue salience, my second main explanatory variable, is based on data from the World Bank Development Indicators for the total population size (or stock) of international migrants and refugees in a country. The World Bank defines the international migrant and refugee stock as "the number of people born in a country other than that in which they live. It also includes refugees." The data underlying this item were originally obtained from national population censuses as well as states' statistics on foreign-born (people who have residence in one country, but were born in another country) or foreign populations (people who are citizens of a country other than the country in which they reside). Hence, this variable captures the entire population of foreign-born individuals in a state. The final variable is logtransformed due to the rather skewed distribution of the original item. While I focus on absolute levels of the foreign-born population, note that all results presented in the following and the appendix are robust when employing changes in the migrant population, i.e., foreignborn population growth or inflows.

Finally, I include a multiplicative, interaction term between Public Opinion and Total Immigration $(\ln )$ to examine whether and how a country's immigration population as a measure of issue salience can moderate the impact of public opinion on national migration controls and regulations.

\section{Controls}

I also include a series of controls, which may affect the dependent variable via alternative channels other than public opinion to avoid omitted variable bias. I primarily follow earlier studies that have a similar focus as my work (see, e.g., Cornelius and Rosenblum 2005; Hansen and Köhler 2005; Howard 2006; Joppke 2003; Givens and Luedtke 2005; Sassen 
2008; Abou-Chadi 2016) and eventually identified the following variables that seem exogenous to the dependent variable, that control for alternative mechanisms influencing the introduction of policy, and that may well be correlated with the core predictors. First, based on the argument that immigration policies and their level of restrictiveness converge over time (e.g., Freeman 1995; Givens and Luedtke 2005; Sassen 2008), I have created a spatial variable measuring the average degree of all states' level of restrictiveness in the previous year. Due to my focus on mostly European states, I do not weigh countries' migration controls and regulations by, e.g., contiguity or geographical proximity. If the convergence argument applies and international forces lead to more and more similar migration policies across national borders (see, e.g., Sassen 2008), we will identify a positive and significant effect stemming from this spatial variable denoted $\boldsymbol{W}$ : Immigration Policiest : , i.e., more restrictiveness abroad increases the level of restrictiveness "at home." However, equally likely may be a free-riding effect in that states systematically lower their restrictiveness levels in response to more controls and restrictive regulations abroad. If this alternative mechanism is valid, the effect of $\boldsymbol{W}$ : Immigration Policies Im $-1_{\text {would }}$ be negatively signed and statistically significant.

Second, the general left-right mean (or median) voter position can be a predictor of attitudes toward migration. The more "conservative" or "right" the general public is, the less likely it will be that it is in favor of migration. The ESS provides the following survey item to measure individuals' left-right self-placement: "people sometimes talk of 'left' and 'right.' Using this card, where would you place yourself on this scale, where 0 means the left and 10 means the right?" Similar to the migration-attitude variable, I averaged values across respondents of each state and year to proxy the left-right mean-voter position in each country-year. In my sample, this item varies between 4.29 and 6.23 with an average value of 5.143, which is slightly above the theoretical average. Third, while all countries in my sample 
are democracies, I still control for variation within this form of government using the polity 2 item from the Polity IV data (Marshall, Gurr, and Jaggers 2016). The average value across all units and years still is very close to the theoretical maximum value of 10 as it stands at 9.65.

Finally, I include three variables that are all taken from the World Bank Development Indicators. These three final items are log-transformed and temporally lagged by one year as well. First, it is frequently argued that countries' migration policies are strongly linked to their economic development (e.g., Freeman 1995: 886). I use GDP per capita (in current US Dollars) to this end, which is defined as the gross domestic product divided by midyear population. GDP is the sum of gross value added by all resident producers in the economy plus any product taxes and minus any subsidies not included in the value of the products. Next to being a measure for the overall economic development in a country, I use the income variable as a proxy for client (business) interests. While data for a large set of countries and years directly covering client interests' influence are hardly available, Coates, Heckelman, and Wilson (2007; see also Fredriksson and Ujhelyi 2005) show that GDP per capita is an important determinant of and strongly correlates with industry interest-group formation. In light of this, GDP per capita should be associated with less restrictive policies when subscribing to the arguments of those studies suggesting that client interests matter and, perhaps, even play a more important role than public opinion (Freeman 1995; Joppke 1999; Beck and Camarota 2002; Sassen 2008; see also Lahav 2004: Facchini and Mayda 2008). Second, population size is likely to be linked to the degree of preference heterogeneity in a society, which in turn could affect the public's demand for migration policies. I rely on a country's midyear total population, which counts all residents regardless of legal status or citizenship (except for refugees not permanently settled). Finally, I consider the influence from unemployment, which I operationalize as the unemployment rate, i.e., the total number of unemployed as a share of the total labor force, which is then log-transformed due to its 
skewed distribution. The term unemployment as such is defined by the World Bank as individuals potentially belonging to the work force, but currently without work and available for and seeking employment. Especially when unemployed, people tend to perceive migration as less favorable (Scheve and Slaughter 2001; Curtis 2014) and policymakers may act accordingly. Table 1 summarizes the descriptive statistics of the variables I have discussed in the research design.

Table 1. Descriptive Statistics

\begin{tabular}{|c|c|c|c|c|c|}
\hline & Obs. & Mean & SD & Min & Max \\
\hline Immigration Policies & 314 & 0.529 & 0.111 & 0.306 & 0.971 \\
\hline Immigration Policiest-1 & 314 & 0.527 & 0.107 & 0.314 & 0.917 \\
\hline Wy: Immigration Policiest-1 & 314 & 0.528 & 0.013 & 0.504 & 0.549 \\
\hline Public Opinion $_{\mathrm{t}-1}$ & 314 & 5.059 & 0.706 & 2.928 & 7.186 \\
\hline Migrant and Refugee Population $\mathrm{t}_{\mathrm{t}-1}$ & 314 & 13.868 & 1.245 & 10.068 & 16.308 \\
\hline Mean Voter $_{t-1}$ & 314 & 5.143 & 0.374 & 4.291 & 6.232 \\
\hline Democracy $_{t-1}$ & 314 & 9.646 & 0.868 & 6.000 & 10.000 \\
\hline Population $_{\mathrm{t}-1}(\ln )$ & 314 & 16.275 & 1.161 & 12.585 & 18.230 \\
\hline GDP per capitat-1 $(\ln )$ & 314 & 10.350 & 0.625 & 8.513 & 11.542 \\
\hline Unemployment Rate $_{\mathrm{t}-1}(\ln )$ & 314 & 1.692 & 0.468 & 0.591 & 3.262 \\
\hline
\end{tabular}

The interaction term is omitted.

\section{Empirical Findings}

Table 2 summarizes the main empirical results. In Model 1, the estimation omits the publicopinion item, but incorporates Migrant and Refugee Population and the controls. Model 2 then adds Public Opinion, while Model 3 is the full model that additionally considers the multiplicative specification of Public Opinion and Migrant and Refugee Population. The coefficients in an OLS model can be interpreted directly as marginal effects. Due to the inclusion of the temporally lagged dependent variable, however, the coefficient estimates reflect the impact in a current year, but I have also calculated the asymptotic long-term effect of the of the core variables following Plümper et al. (2005: 336). Moreover, as for the interaction in Model 3, its constituent variables' sizes, signs, or standard errors cannot be 
directly interpreted. Figure 2 thus depicts the average marginal effect of Public Opinion for the values of Migrant and Refugee Population to allow for an intuitive interpretation.

Table 2. Public Opinion and Migration Policies

\begin{tabular}{|c|c|c|c|}
\hline & Model 1 & Model 2 & Model 3 \\
\hline Immigration Policiest-1 & $\begin{array}{l}0.979 * * * \\
(0.050)\end{array}$ & $\begin{array}{l}0.980 * * * \\
(0.049)\end{array}$ & $\begin{array}{l}0.969 * * * \\
(0.052)\end{array}$ \\
\hline Wy: Immigration Policies t- $_{1}$ & $\begin{array}{c}0.400 \\
(0.416)\end{array}$ & $\begin{array}{c}0.460 \\
(0.390)\end{array}$ & $\begin{array}{c}0.669 \\
(0.424)\end{array}$ \\
\hline Public Opinion $_{t-1}$ & & $\begin{array}{c}0.009^{*} \\
(0.005)\end{array}$ & $\begin{array}{l}-0.086^{* *} \\
(0.037)\end{array}$ \\
\hline Migrant and Refugee Population ${ }_{t-1}$ & $\begin{array}{l}-0.017 \\
(0.010)\end{array}$ & $\begin{array}{l}-0.015 \\
(0.010)\end{array}$ & $\begin{array}{l}-0.049 * * \\
(0.018)\end{array}$ \\
\hline Public Opinion ${ }_{t-1} *$ Migrant and Refugee Population $_{\mathrm{t}-1}$ & & & $\begin{array}{l}0.007 * * \\
(0.003)\end{array}$ \\
\hline Mean Voter $\mathrm{t}_{-1}$ & $\begin{array}{c}0.004 \\
(0.008)\end{array}$ & $\begin{array}{c}0.006 \\
(0.008)\end{array}$ & $\begin{array}{c}0.006 \\
(0.008)\end{array}$ \\
\hline Democracy $_{\mathrm{t}-1}$ & $\begin{array}{l}-0.019^{* * *} \\
(0.003)\end{array}$ & $\begin{array}{l}-0.019 * * * \\
(0.004)\end{array}$ & $\begin{array}{l}-0.018^{* * *} \\
(0.003)\end{array}$ \\
\hline Population $_{\mathrm{t}-1}(\ln )$ & $\begin{array}{l}0.166^{* *} \\
(0.061)\end{array}$ & $\begin{array}{l}0.161^{* * *} \\
(0.056)\end{array}$ & $\begin{array}{l}0.168 * * * \\
(0.053)\end{array}$ \\
\hline GDP per capitat-1 $(\ln )$ & $\begin{array}{c}-0.030^{*} \\
(0.016)\end{array}$ & $\begin{array}{l}-0.030^{*} \\
(0.016)\end{array}$ & $\begin{array}{c}-0.038^{* *} \\
(0.017)\end{array}$ \\
\hline Unemployment Rate $_{t-1}(\ln )$ & $\begin{array}{l}-0.012 * * \\
(0.005)\end{array}$ & $\begin{array}{l}-0.012 * * * \\
(0.004)\end{array}$ & $\begin{array}{l}-0.014 * * * \\
(0.004)\end{array}$ \\
\hline Constant & $\begin{array}{c}-2.412^{* *} \\
(0.914)\end{array}$ & $\begin{array}{c}-2.433 * * * \\
(0.859)\end{array}$ & $\begin{array}{l}-2.125^{* * *} \\
(0.798)\end{array}$ \\
\hline Obs. & 314 & 314 & 314 \\
\hline RMSE & 0.017 & 0.017 & 0.017 \\
\hline Country Fixed Effects & Yes & Yes & Yes \\
\hline Temporal Fixed Effects & Yes & Yes & Yes \\
\hline
\end{tabular}

Table entries are coefficients; standard errors clustered on country in parentheses.

$* \mathrm{p}<0.10,{ }^{* *} \mathrm{p}<0.05, * * * \mathrm{p}<0.01$

Starting with a discussion of the main explanatory variables, Model 1 demonstrates that issue salience, which I capture via the total number of refugees and migrants in a country, exerts little impact on the degree of restrictiveness of migration policies on its own. The effect of Migrant and Refugee Population is negatively signed, but statistically insignificant. When adding Public Opinion to the estimation as in Model 2, this result remains unchanged. That said, the item on migration attitudes, Public Opinion, is positively signed and statistically significant at the 10 percent level. In substantive terms, raising Public Opinion by 
one unit leads to a short-term increase in internal-policy restrictiveness of 0.009. Also in the short run, increasing Public Opinion from its minimum to its maximum induces a change from 0.510 to 0.547 in Immigration Policies. The long-term effect is more substantive: asymptotically, immigration restrictions are raised by 0.436 if the public mood towards migration becomes worse (i.e., if Public Opinion is increased) by one unit. Yet, the impact of public attitude is only barely significant, suggesting that opposite forces might be at work that dampen and go against the impact of Public Opinion.

Model 3 is the fully-specified estimation that incorporates the interaction between Public Opinion and Migrant and Refugee Population. Figure 2 summarizes the substantive quantities of interest of that model's core variables. On one hand, for low to medium-sized migrant and refugee populations, the effect of Public Opinion is, in fact, statistically insignificant. On the other hand, in country-years with larger foreign-born populations, Public Opinion is positive and highly statistically significant. At the maximum of the moderating variable (Migrant and Refugee Population), the average marginal effect of Public Opinion is around 0.025 in the short term and 0.810 in the long term. The cut-off value, i.e., that value of Migrant and Refugee Population that divides significant from insignificant impacts of Public Opinion, is at around 940,000 of foreign-born individuals living in a country. In more substantive terms, in countries with rather small migrant and refugee populations such as Slovakia or Finland, the public's generally less favorable view towards migration is unlikely to significantly affect domestic immigration regulations and controls. Only in states with a large number of migrants and refugees, e.g., the UK, the Netherlands, or Germany, population movements are seen as a salient issue - and then the public mood is "activated" and can influence domestic policy-making. 
Figure 2. Average Marginal Effects of Public Opinion on Immigration Policies

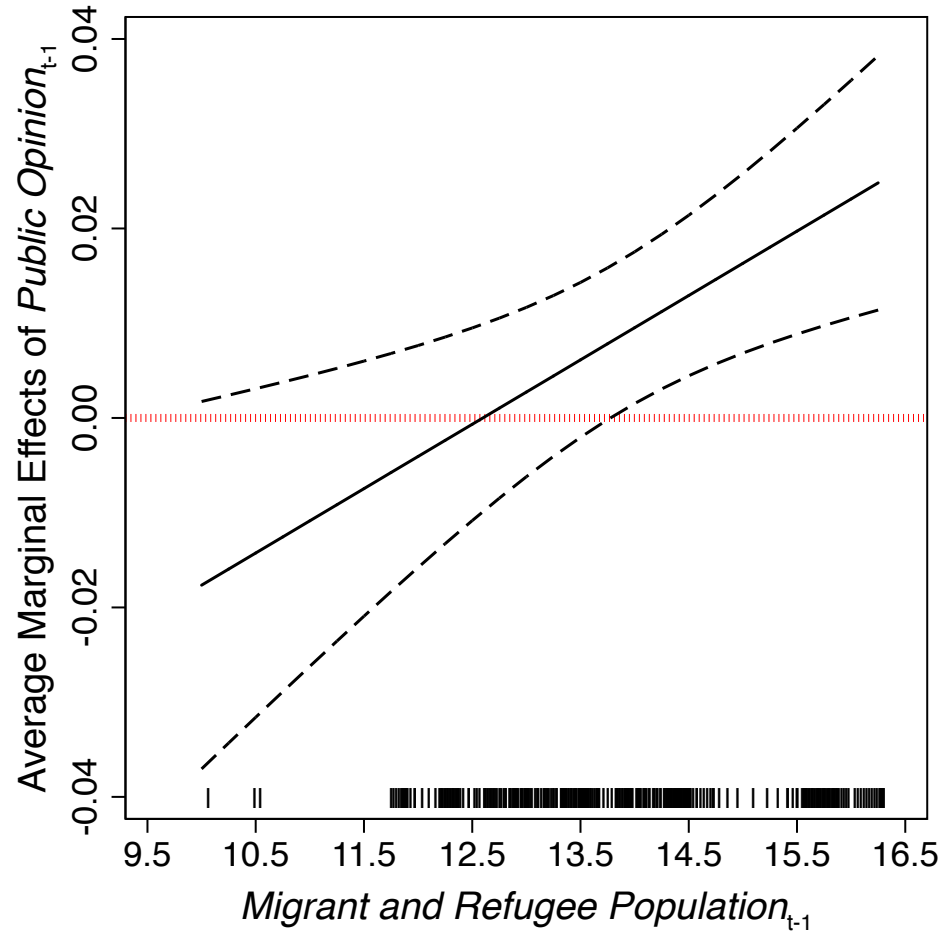

Note: Graph shows average marginal effects of Public Opinion for various values of Migrant and Refugee Population, while holding all other covariates constant at their means; dashed lines signify 90 percent confidence intervals; rug plot at horizontal axis illustrates distribution of Migrant and Refugee Population; red dotted line marks marginal effect of 0 .

Linking these results back to the theoretical argument, the analysis provides strong support for the conditional claim, i.e., that issue salience moderates the impact of the general, public mood on national migration policies; and it thereby also lends support to the argument that in cases of low issue salience, the opposing effects stemming from the public views on migration and more organized, client interests cancel each other out, leading to the overall insignificance of Public Opinion in country-years with rather small foreign-born populations. Hence, I demonstrate that there is some validity surrounding the dominant claim in existing literature that client interests exert an influence on migration policies, but also that public opinion matters, too, working against client interests and even dominating them in highsalience situations, where the public's view is activated and governments seek to follow the arguably less-organized, but then in terms of size more relevant, critical mass of voters: if 
public opinion becomes more skeptical and less supportive of migration, policy-makers react; but, again, only in cases of issue salience and rather high migrant and refugee populations.

In terms of the control variables, quite a few of them are associated with significant effects despite the inclusion of fixed effects models that make it more difficult to draw inferences about time-invariant or slow-moving variables (Plümper and Troeger 2007). ${ }^{7}$ First, the spatial variable, Wy: Immigration Policies, is insignificant, though, providing insufficient support for the argument that immigration policies converge more and more toward more liberal regulations; this mirrors the pattern depicted in Figure 1 above. Second, Democracy exerts a significant and negative impact on the level of restrictiveness of migration policies (see also Koopmans and Michalowski 2017: 46). However, the overall substance of the estimated effect should not be over-interpreted due to the lack of variance for the regime-type item: all countries in the sample are democracies with a mean-polity2 score of 9.65 .

Third, more economically developed states are less restrictive on their immigration policies as demonstrated by the negative and significant estimate for GDP per capita in Table 2. Substantively, in the short term, increasing income by 10 percent is associated with a decrease in the level of restrictiveness by 0.002 units in the next year. In general, this pattern seems to support the claim, including those studies I pointed to above, that the organized, economic interest tends to favor migration due to the various benefits it provides. More economically developed and wealthier states are then, unsurprisingly, linked to less restrictive policies. The result for Unemployment Rate is at first sight somewhat surprising in that higher unemployment rates are associated with less restrictive regulations and controls. There are two potential explanations for this. First, Bello (2017: 27), among others, argues that "unemployed are not more prejudiced against immigrants than are the employed" (see also Lahav 2004: 1168; Ceobanu and Escandell 2010; Hainmueller and Hiscox 2010). A

\footnotetext{
${ }^{7}$ This is because (almost) time-invariant covariates are highly collinear with fixed effects and their coefficients are then either not identified or difficult to estimate with precision.
} 
finding that a higher unemployment rate has to be associated with more restrictive policies does not necessarily follow from that. In addition, secondly, the pattern I identify might be associated with more organized influence stemming from the industrial sector and that business actors usually see migration as beneficial (see also Givens and Luedtke 2005: 5). In times of unemployment, my finding suggests that industry has successfully lobbied against more restrictive laws to, e.g., attract cheap labor from abroad. These are both possible explanations for the effect I report for Unemployment Rate, but I leave it to future research to examine this interesting pattern in more depth than the scope of my article warrants.

Finally, Population is, as expected, positively signed and significant. Increasing a country's population by 10 percent is linked to a rise of 0.007 units in migration-policy restrictiveness in Model 3. As argued above, population size is likely to be linked to the degree of preference heterogeneity in a society, which in turn could affect the public's demand for migration policies.

\section{Conclusion}

The literature has extensively studied the determinants of states' migration policies, usually focusing on client interests that, small in size but well-organized, can influence the direction of domestic laws and regulations on immigration significantly (Freeman 1995; Joppke 1999; Beck and Camarota 2002; Sassen 2008; see also Lahav 2004). Due to the lack of highquality, comparative data covering a larger set of countries and years, however, rigorous and systematic empirical testing of such and similar claims has been difficult (see also Freeman 1995: 887; Meyers 2000; Lahav 2004: 1178; Money 2010; Abou-Chadi 2016: 2087), and more case-specific and descriptive work informed our understanding. With the release of the IMPIC data (Helbling et al. 2017), cross-country analyses became feasible and my research is 
one of the first studies making use of this source of information for re-assessing the determinants of countries' migration policies from a cross-national perspective.

In a first step, I presented descriptive patterns, which raised doubts about previous arguments on a policy convergence process towards a "liberal bias" (Money 2010), and suggested that the virtually exclusive role of client interests may not necessarily be valid. Instead, I identified a significant amount of variation in countries' immigration policies, making it plausible that previously overlooked factors may be more influential than existing work does suggest. To this end, I primarily focused on public opinion and the general public's view toward migration. On one hand, I developed the claim that democratic policymakers have incentives to provide public goods to their domestic audience and to implement policies that the electorate sees favorably. The empirical evidence then supported this claim, brining-back in public opinion as an important determinant of states' migration regulations and controls. That said, the corresponding item was only barely significant, suggesting that other, arguably opposing mechanisms were at work, too - client politics.

The conditional argument I developed addressed this. While public opinion can influence domestic migration policies, we should not rule out the impact of the more organized client interests and the results for my income variable underline the importance of this factor (Freeman 1995; Joppke 1999; Beck and Camarota 2002; Sassen 2008; see also Lahav 2004: Facchini and Mayda 2008). In light of this, I contended that an effect stemming from public opinion on migration policies should only materialize when the migration issue is salient that is, when the size of the foreign-born population is large and many migrants and refugees reside in a focal country. Only under those circumstances can the general public mood exert an influential effect different and independent from client politics as, while mostly unorganized, their size can be key for affecting whether a government stays in power or not. Ultimately, I therefore combine the influences stemming from client interests and the 
unorganized public, showing that both are relevant for explaining migration policies, although the general public's interests emerge as the more important, the key influence in times of migration being a salient issue. And this rejects earlier conclusions that "public opinion in liberal democracies is slower to mobilize and crystalize" (Freeman 1995: 884).

This research offers important policy implications. First, most importantly, I contribute to the larger debate on whether politicians respond to what voters want or if parties and governments merely push for their own agenda (see Huber and Powell 1994; Stimson et al. 1995; Powell 2000). My work presents strong and robust evidence that governments react to the preferences of the public, which mirrors, e.g., Ezrow (2010) who finds parties to be votemaximizing and center-oriented. Second, given the increasing importance of migration in Europe, my work clearly shows that public opinion sets the constraints in which policy can develop, offering more practical guidance on how we can explain the form of migration laws. The public is important, but interest groups that are usually in favor of more open policies now know when and under what circumstances they might have to "do more" in order to be effective.

Third, in light of current plans to implement an EU-wide migration and refugee quota and distribution program, my research suggests that this - if well designed and implemented at the right time - may crucially influence whether and to what degree the public can influence policies and the latter then becoming more restrictive. Effectively re-distributing migrants and refugees affects whether population inflows are seen as a salient issue - and whether policymakers then have to pay more attention to what the public wants and what it does not. Finally, my work offers implications the rise of populist and far-right, anti-immigration party platforms as well as the positions that parties assume in times of elections. Consider, for example, the 2017 German and Austrian national elections where most parties sought to emphasize immigration policymaking in light of increasing issue salience and a public more 
and more concerned about immigration (see also Thränhardt 1995). Political parties can be "nudged" to adopt more restrictive policy platforms (Cornelius and Rosenblum 2005: 104) and public opinion in times of issue salience clearly seem a key driving force here.

In terms of future research, one avenue might be to strengthen our efforts to investigate what causes public opinion on migration in the first place. Many studies analyze the factors affecting beliefs using individual-level predictors (see, e.g., Ceobanu and Escandell 2010; Galleo and Pardos-Prado 2014; Hainmueller and Hopkins 2014). However, it is still unclear what shapes public opinion at the macro level. If groups understood this dynamic, public opinion could be (purposefully) shifted as a means to catalyze the passage of policy at the federal level. Moreover, I treated different types of policies similarly. An interesting next step could be to differentiate policies and see whether public opinion leads to a particular set of policies being implemented. ${ }^{8}$ In addition, Money (2010), among others, distinguishes between immigration controls and immigration integration. The question remains whether the patterns I have identified here also work in the context of the latter, although data on integration efforts are less widely available than on laws and controls. Finally, salience is a difficult concept to measure. I eventually opted for the size of the foreign-born population as a proxy, but other variables seem equally plausible, e.g., crime or acts of terrorism committed by migrants. However, such data are available for some country-years, but not all; and data availability for media coverage of migration, another plausible proxy suggested in the literature (Epstein and Segal 2000), are even more sparse. More data collection efforts will be necessary as a result to address these issues and other important questions in the nexus of public opinion and migration policies.

\footnotetext{
${ }^{8}$ The appendix offers a preliminary robustness check to this end, though.
} 


\section{References}

Abou-Chabi T. (2016) Political and Institutional Determinants of Immigration Policies. Journal of Ethnic and Migration Studies 42(13): 2087-2110.

Alarian H., Wallace Goodman S. (2017) Dual Citizenship Allowance and Migration Flow: An Origin Story. Comparative Political Studies 50(1): 133-167.

Baumgartner F., and Jones B. (1993) Agendas and Instability in American Politics. Chicago, IL: University of Chicago Press.

Beck N. (2001) Time-Series-Cross-Section Data: What Have We Learned in the Past Few Years? Annual Review of Political Science 4(1): 271-293.

Beck R., and Camarota S. (2002) Elite vs. Public Opinion: An Examination of Divergent Views on Immigration. Washington, DC: Center for Immigration Studies.

Bélanger É., and Meguid B. (2008) Issue Salience, Issue Ownership, and Issue-Based Vote Choice. Electoral Studies 27(3): 477-491.

Bello V. (2017) Interculturalism as a New Framework to Reduce Prejudice in Times of Crisis in European Countries. International Migration 55(2): 23-38.

Breunig C., Cao X., and Luedtke A. (2012) Global Migration and Political Regime Type: A Democratic Disadvantage. British Journal of Political Science 42(4): 825-854.

Bueno de Mesquita B., Smith A., Siverson R. and Morrow J. (2005) The Logic of Political Survival. Cambridge, MA: MIT Press.

Ceobanu A., and Escandell X. (2010) Comparative Analyses of Public Opinion Toward Immigrants and Immigration Using Multinational Survey Data: A Review of Theories and Research. Annual Review of Sociology 36(1): 309-328.

Citrin J., Green D., Muste C., and Wong C. (1997) Public Opinion Toward Immigration Reform: The Role of Economic Motivations. Journal of Politics 59(3): 858-881. 
Coates D., Heckelman J.., and Wilson B. (2007) Determinants of Interest Group Formation. Public Choice 133(3/4): 377-391.

Cornelius W., and Rosenblum M. (2005) Immigration and Politics. Annual Review of Political Science 8(1): 99-119.

Curtis A. (2014) Inclusive versus Exclusive: A Cross-National Comparison of the Effects of Subnational, National, and Supranational Identity. European Union Politics 15(4): 521546.

Dahl R. (1971) Polyarchy - Participation and Opposition. New Haven, CT: Yale University Press.

de Vries, C. (2017). Cross-National Data Sources: Opportunities \& Challenges. In: k. Arzheimer, J. Evans, and M. Lewis-Beck. Sage Handbook of Electoral Behavior. New York: Sage Press, pp. 962-981.

Downs A. (1957) An Economic Theory of Democracy. New York: Harper \& Brothers.

Dustmann, C., and Frattini T. (2014) The Fiscal Effects of Immigration to the UK. Economic Journal 124(580): F593-F643.

Epstein L., Segal J. (2000) Measuring Issue Salience. American Journal of Political Science 44(1): 66-83.

Ezrow L. (2010) Linking Citizens and Parties. Oxford: Oxford University Press.

Facchini G., and Mayda A. (2008) From Individual Attitudes towards Migrants to Migration Policy Outcomes: Theory and Evidence. Economic Policy 23(56): 651-713.

Flink C. (2015) Rethinking Punctuated Equilibrium Theory: A Public Administration Approach to Budgetary Changes. Policy Studies 45(1):101-120.

Freeman G. (1995) Modes of Immigration Policies in Liberal Democratic States. International Migration Review 29(4): 881-902. 
Fredriksson P., and Ujhelyi G. (2005) Political Institutions, Interest Groups, and the Ratification of International Environmental Agreements. University of Louisville, KY: Typescript.

Galleo A., and Pardos-Prado S. (2014) The Big Five Personality Traits and Attitudes towards Immigrants. Journal of Ethnic and Migration Studies 40(1): 79-99.

Geels F. (2013) The impact of the financial-economic crisis on sustainability transitions: Financial investment, governance and public discourse. Environmental Innovation and Societal Transitions 6(1): 67-95.

Givens T., and Luedtke A. (2005) European Immigration Policies in Comparative Perspective: Issue Salience, Partisanship, and Immigrant Rights. Comparative European Politics 3(1): 1-22.

Hainmueller J., Hangartner D., and Pietrantuono G. (2017) Catalyst or Crown: Does Naturalization Promote the Long-Term Social Integration of Immigrants? American Political Science Review 111(2): 256-276.

Hainmueller J., Hiscox M. (2010) Attitudes toward Highly Skilled and Low-Skilled Immigration: Evidence from a Survey Experiment. American Political Science Review 104(1): 61-84.

Hainmueller J., and Hopkins D. (2014) Public Attitudes Toward Immigration. Annual Review of Political Science 17(1): 225-249.

Hansen R., and Köhler J. (2005). Issue Definition, Political Discourse and the Politics of Nationality Reform in France and Germany. European Journal of Political Research 44(5): 623-644.

Helbling M., Bjerre L., Römer F., and Zobel M. (2017) Measuring Immigration Policies: The IMPIC Database. European Political Science 16(1): 79-98.

Helbling M., and Kalkum D. (2018) Migration Policy Trends in OECD Countries. Journal of European Public Policy: Forthcoming. 
Howard M. (2006) Comparative Citizenship: An Agenda for Cross-National Research. Perspectives on Politics 4(3): 443-455.

Howard M. (2009) The Politics of Citizenship in Europe. Cambridge: Cambridge University Press.

Howard M. (2010) The Impact of the Far Right on Citizenship Policy in Europe: Explaining Continuity and Change. Journal of Ethnic and Migration Studies 36(5): 735-751.

Huber J., and Powell B. (1994) Congruence between Citizens and Policymakers in Two Visions of Democracy. World Politics 46(3): 291-326.

John P. (2012) Analyzing Public Policy. Abingdon: Routledge.

Johnson E., Agone J., and McCarthy J. (2010) Movement Organizations, Synergistic Tactics and Environmental Public Policy. Social Forces 88(5): 2267-2292.

Jones B. (1994) Reconceiving Decision-making in Democratic Politics: Attention, Choice, and Public Policy. Chicago: University of Chicago Press

Jones B., and Baumgartner F. (2005) The Politics of Attention: How Government Prioritizes Problems. Chicago: University of Chicago Press

Jones B., and Baumgartner F. (2012) From There to Here: Punctuated Equilibrium to the General Punctuation Thesis to a Theory of Government Information Processing. Policy Studies 40(1): 1-19.

Joppke C. (1999) Immigration and the Nation-State. Oxford: Oxford University Press.

Joppke C. (2003) Citizenship between De- and Re- Ethnicization. European Journal of Sociology 44(3): 429-458.

Kessler A., and Freeman G. (2005) Public Opinion in the EU on Immigration from Outside the Community. Journal of Common Market Studies 43(4): 825-850. 
King G., Tomz M., and Wittenberg J. (2000) Making the Most of Statistical Analyses: Improving Interpretation and Presentation. American Journal of Political Science 44(2): $347-361$.

Koopmans R., and Michalowski I. (2017) Why Do States Extend Rights to Immigrants? Institutional Settings and Historical Legacies Across 44 Countries Worldwide. Comparative Political Studies 50(1): 41-74.

Lahav G. (2004) Public Opinion Toward Immigration in the European Union. Does It Matter? Comparative Political Studies 37(10): 1151-1183.

Marshall Monty G., Gurr T., and Jaggers K. (2016) Polity IV Project. Political Regime Characteristics and Transitions, 1800-2015. Dataset Users' Manual. Center for Systemic Peace.

Mazey S., and Richardson J. (2006) Interest Groups and EU Policy-Making. In J. Richardson. European Union: Power and Policy Making. London: Routledge, 217-237.

Meyers E. (2000) Theories of International Immigration Policy: A Comparative Analysis. International Migration Review 34(4): 1245-1282.

Mirolovic N. (2010) Explaining the Politics of Immigration: Dictatorship, Development, and Defense. Comparative Politics 42(3): 273-292.

Money J. (2010) Comparative Immigration Policy. In: R. Denemark. The International Studies Encyclopedia. Chister: Wiley-Blackwell.

Plümper T., and Troeger V. (2007) Efficient Estimation of Time-invariant and rarely Changing Variables in Finite Sample Panel Analyses with Unit Fixed Effects. Political Analysis 15(2): 124-39.

Powell B. (2000) Elections as Instruments of Democracy: Majoritarian and Proportional Visions. New Haven, CT: Yale University Press. 
Sassen S. (2008) Territory, Authority Rights: From Medieval to Global Assemblages. Princeton: Princeton University Press.

Scheve K., and Slaughter M. (2001) Labor Market Competition and Individual Preferences over Immigration Policy. Review of Economics and Statistics 83(1): 133-145.

Sides J., and Citrin J. (2007) European Opinion About Immigration: The Role of Identities, Interests and Information. British Journal of Political Science 37(3): 477-504.

Stimson J., Mackuen M., and Erikson R. (1995) Dynamic Representation. American Political Science Review 89(3): 543-565.

Thränhardt, D. (1995) The Political Uses of Xenophobia in England, France, and Germany. Party Politics 1(3): 323-345.

Ugur M. (1995) Freedom of Movement vs. Exclusion: A Reinterpretation of the "InsiderOutsider” Divide in the European Union. International Migration Review 29(4): 965-999.

Walgrave S., and Dejaeghere Y. (2016) Surviving Information Overload: How Elite Politicians Select Information. Governance 30(2): 229-244.

Wlezien C. (1995) The Public as Thermostat: Dynamics of Preferences for Spending. American Journal of Political Science 39(4): 981-1000. 